\title{
The Impact of Sale and Leaseback on Commercial Real Estate Prices and Initial Yields in the UK
}

\section{Abstract}

This research evaluates the impact of Sale and Leaseback (SLB) on UK commercial property prices and yields, compared with arms-length transactions. Data on 357 SLB deals and 1266 non-SLB deals is extracted from CoStar and Estates Gazette.

Independent-samples t-tests and hedonic regressions and comparative analysis with the risk-free rate are undertaken. In addition to the SLB dummy variable, explanatory variables include building size, quality, age, sector, location and year of transaction.

SLB transactions are found to occur at a statistically significant price premium of around $20 \%$ compared with non-SLB properties, with the greatest premium occurring in the office sector. The net initial yield of the SLB transaction sample is around 2 percentage points lower than for the non-SLB sample in every sector. Comparison with Government 10-Year Bond rates puts the results into perspective, with SLB properties achieving a 4.5 percentage point premium compared with the risk-free rate. Reasons for these differences are probed by considering the effect of WAULT and tenant covenant strength.

From a vendor's perspective, the findings give an indication of the price premium they might be able to negotiate for their property compared with market prices. This will help them assess whether SLB is worthwhile compared with other available financing options. For potential purchasers, knowledge of the order of magnitude of price premiums for SLB can be used to determine an appropriate offer price. The findings of a yield reduction is helpful for institutional investors to enable them to decide whether to engage in SLB investment. 


\section{Introduction}

Sale and Leaseback of real estate (SLB) is one of the financing devices which companies can use to raise capital for investment in their business. This method was widely adopted by companies after World War II in response to the capital expansion requirement (Tipping and Bullard, 2007). The principle of SLB involves the sale of land and building(s) to a third party, and simultaneously the previous owner leases it back from the third party, typically on a long lease of twenty to thirty years (Cary, 1947). Sale and Leaseback transactions (SLBTs) may comprise a series of lease arrangements whereby the lessee agrees to pay building insurance, maintenance costs, as well as minor alterations and building improvements - a 'triple net lease'. This arrangement helped with the post-war pressure for expansion of commercial and industrial facilities postponed throughout the war, without disturbing the capital structure of the company (Wilson, 1953). Also, the emergence of institutional investors who actively seek satisfactory investments for their funds increased the popularity of SLB. Thus Sale and Leaseback can be mutually beneficial for both parties.

In the United Kingdom (UK), SLB began in the 1920s, with retail trading groups led by Charles Clore using the method to raise capital (Thontteh, 2013). The popularity of SLBTs in the UK increased in the 1970s and early 1990s (Adams and Clarke, 1996), and at the beginning of the twenty-first century several FTSE-100 companies adopted the SLB arrangement for their portfolio disposal (Tipping and Bullard, 2007). These corporations were mainly retail banks, hotel chains, supermarkets, and leading high street retailers. Examples include Barclays, Tesco, Royal Bank of Scotland Group and the disposal of 44 branches of Lloyds Bank in 2017 Q1 (EGI, 2017). This method of raising capital has become mainstream to the holding of operational property over the past twenty years because of its flexible adaptation to changing market conditions. 
Although SLB is considered to provide a good return on investment for the buyer due to the amortization of rental payment on the transaction price, typically at a higher interest rate than the mortgage loan (Wilson, 1953; Homburger and Andre, 1989), there have been limited empirical studies of the impact of SLB on commercial real estate values, particularly on prices and returns. The earlier research mostly focused on the effect of accounting rules and the impact on corporate value by analysing changes in the share price of the seller - lessee (Rutherford, 1990; Fisher, 2004; Grönlund, Louko and Vaihekoski, 2008). Other SLB research concentrating on the motivations of the seller and buyer has been undertaken by Barris (2002), Whittaker (2008) and Ling (2012). The study of yield is important since, in addition to lease length, it is a key factor influencing SLBT price (Hordijk, Rompelman and Koerhuis, 2010). In completing such a SLBT, the return must compare favourably to alternative investments available in the market.

The primary objective of this research is to investigate the impact of SLB on commercial property prices and returns in the UK. The commercial properties here consist of office, industrial, retail, and other commercial sectors, including healthcare, sports and entertainment, hospitality, and leisure. The transactions comprise properties for which net initial yield, defined as "The current annualised rent, net of costs, expressed as a percentage of capital value, after adding notional purchaser's costs" (MSCI, 2015), and sale price information, are available.

The research aims to answer the following questions:

- Is there a difference in the sale price and net initial yield for SLB and non-SLB transactions?

- If so, can differences be accounted for by lease length and tenant covenant strength?

The null hypothesis is that SLB does not affect commercial property price or rate of return. 
However, if a difference does exist it would be expected that SLB properties would achieve a higher sale price, or a lower yield compared to non-SLB. This is because SLB is regarded as a relative safe investment due to the nature of the guaranteed long term lease which reduces the risk of vacancy during the lease period (Cary, 1948; Wilson, 1953; Sirmans and Slade, 2010). Therefore, the investor is likely to be willing to pay a premium for SLB properties.

This paper examines the impact of the SLB arrangement on commercial real estate prices and yields. Section 2 provides a brief review of relevant literature to provide insight into the motivations of seller and buyer in completing such SLB transactions. Additionally, findings from earlier SLB research are discussed. Section 3 explains the quantitative methodology of this research. This comprises: independent samples t-tests to compare the mean values of the dependent variables - sale price and net initial yield - for the SLB and non-SLB samples yearby-year; analysis by property sector; and hedonic regression modelling. The data is described in Section 4 and analysed in Section 5. Section 6 investigates the effect of Weighted Average Unexpired Lease Term (WAULT) and tenant covenant strength for those transactions where this data is available, while in Section 7 the practical implications of the findings are discussed. 


\section{Literature Review}

\section{Sale and Leaseback}

One of the earlier studies of sale and leaseback arrangements was carried out by Wilson (1953) who elaborated three common steps of this deal:

(1) A business corporation that owns real estate sells its property to a life insurance company or charitable institution at the depreciated book value;

(2) At the same time as the sale, the company obtains a long-term lease of the property, typically up to thirty years, at a rental price which provides the full amortization over the transaction price plus a net return of $3.5 \%$ to $4.5 \%$ over the lease period;

(3) Additionally, there are specific lease arrangements whereby the lessee agrees to pay the cost of maintenance and minor improvements to the building.

This principle concurs with Cary (1947), who adds an option to renew the lease by an additional twenty or thirty years, and the possibility of buy-back options. This rental agreement will vary and may differ according to the rent paid. In the UK and Australia, it is common to have upward only rent reviews, whereas in a market like New Zealand, upwards-only rent reviews contravene contract legislation (Ward et al., 2006). Besides the rent, the value of the repurchase options will be appraised by independent appraisal at the same time. This value depends upon the property quality, the needs of both of the parties in terms of lease length, as well as property management issues (Grönlund, Louko and Vaihekoski, 2008). Thus, the SLBT is individually tailored, making it near-impossible to prescribe precisely the form which it takes.

Regarding SLBT actors, the retail industry pioneered the SLBT arrangement, with life insurance companies and pension funds being the first investors in SLB (Brunie, 1960). SLBTs 
have generally taken place in a non-property sector business, i.e. property is not their core business. However, the actors vary substantially nowadays, from leading FTSE 100 companies, to public auction houses and telecom industries. Furthermore, at the start of the 2000s, many UK corporations had adopted the concept of selling their portfolio of properties to one single investor in a SLB arrangement (Tipping and Bullard, 2007). Table 1 gives examples of notable SLB transactions during 2010-2017 (Note these are portfolio transactions and are not used for the analysis in this paper, which uses only individual property transactions for which sale price and net initial yield data is available).

\section{INSERT TABLE 1 HERE}

\section{Motivation for Sale and Leaseback}

The primary objective from a seller's perspective in undertaking SLB is the finance motive of releasing capital from real estate ownership (Devaney and Lizieri, 2004; Hordijk, Rompelman and Koerhuis, 2010). This new capital can be used for company expansion in the core business sectors, while retaining occupation of the premises. This capital should achieve a higher return in the seller's company cash flow compared to continuing the property ownership, even allowing for rent payments. Whilst a key motive for completing a SLBT is releasing equity from a company's real estate portfolio at the best possible price, a company's motives may differ. For example in Table $\mathbf{1}$ above, Tesco was looking to raise equity from its real estate portfolio in a tax efficient way to help grow its business (Evans, 2013). Lloyds, on the other hand, disposed of some secondary properties to reduce outgoings after the financial crash, as they were not fundamental to its long term strategy (Morgan Pryce, 2017). Performing a SLBT on these properties achieved a higher price than merely selling an empty property. Both Tesco and Lloyds created a SLB structure to maximise the sale price they could achieve, albeit for different reasons. 
Prior to the new International Accounting Standards (FASB, 2016) which oblige companies to recognise all leases as liabilities on the balance sheet, another motive for SLBT was for accounting purposes. Operating leases used to be treated off balance sheet, thus improving accounting ratios and appearing to create a more healthy cash flow (Hodge, 1986; McCarthy, 1989). (This motive is no longer relevant because all leases longer than 1-year must be treated as Finance leases, with rent obligations shown on the balance sheet).

SLB may be particularly valuable for small companies which often have a high cost of debt and require fast financing for their expansion. Of course, such companies would provide a less secure income stream as they might be more vulnerable to takeovers or bankruptcy, so might find it harder to find an investor willing to purchase their properties. Large companies, such as British Telecom in 2001, are more likely to find a willing buyer for their portfolio (Devaney and Lizieri, 2004).

Additional motives for the seller include increasing shareholder value in the lessee company. A study by Slovin et al. (1990) discovered a positive stock price response for companies who deployed a SLB strategy. They concluded that SLBT generates positive wealth for the seller and that this benefit is attributable to the present value of tax deductions. Furthermore, a comparison study between SLBT and direct leasing completed by Ezzell and Vora (2001) found that SLB is related to a rise in equity and that this depends on the types of properties leased. This is in line with a study by Pottinger et al. (2002), who concluded that SLB will result in an increase in shareholder value, particularly in reported net assets. Other studies reporting positive stock market reactions to announcements of SLB include Rutherford, 1990; Devaney and Lizieri, 2004; and Fisher, 2004). Lasfer (2007) has analysed the optimal proportion of corporate property that should be rented rather than owned to maximise shareholder returns. Companies might choose to sell and leaseback some of their real estate to 
achieve the occupational efficiency that is the basis for such optimisation, although in part it was achieved through the accounting device of an operating lease, referred to above. Further possible reasons for a company to pursue SLB is to dispose of undervalued properties that might be a magnet for a hostile takeover bid (McClary, 2006) and to gain additional flexibility with future location and accommodation requirements (Tipping and Bullard, 2007).

From the property purchaser's perspective, motivation for buying property relates to yield and return, together with factors such as portfolio diversification. Yield and return have a major influence in determining the price of a property in a SLBT (Torrey, 1954). The investor will calculate the investment yield which is likely to be obtained by a SLBT and compare this to alternative investment devices available in the market. Also, the credit rating of the lessee ought to affect the decision (Cary, 1949; Bryan, 2003). As discussed above, investors may be unwilling to buy a property let on a long lease to a financially weak tenant in case they cannot afford to pay the rent. Therefore, SLBT tends to be carried out by financially strong occupiers (Sirmans and Slade, 2010). Such companies tend to occupy a good quality building, giving an investor the opportunity to purchase a property let on a long lease to a tenant of good covenant strength. This may encourage them to pay a premium price, although research by Hutchison, Adair and McWilliam (2008); and by Hutchison, Adair and Findlay $(2009,2011)$ has found that returns from properties occupied by tenants of good ex ante covenant strength, measured by ratings agencies such as Experian or Dun \& Bradstreet (dun\&bradstreet, 2018), do not necessarily exceed those achieved by properties occupied by tenants deemed to be of poorer covenant strength. Indeed, predicting likelihood of tenant failure is not easy. The 2008 research (ibid) showed some retailers to be of the highest covenant strength only a short while before they went into administration (e.g. Woolworths), while the now highly successful retailer Lidl was deemed to be in the highest risk category in 2002, and subsequently of moderate risk. The 
more significant aspect determining returns was found to be the length of lease, with investors lowering their required yield when a property combined a long lease with a financially secure tenant.

\section{Effect on Price and Yield of Sale and Leaseback Transactions}

When considering rental terms and price paid, the transaction price of SLBT is not necessarily the depreciated book value. Price might be affected by taxes payable, such as stamp duty land tax (payable by the buyer) and capital gains tax (payable by the seller), and by specific lease provisions. If the contract period is unusually long, or contains other written covenants that would not be considered standard and which have impacted the price, then the price may need adjustment to reflect 'normal' lease terms in the prevailing market. RICS (2015) suggests that the lease payment in a SLBT is either rack rent or another value related to purchase price for a fixed period. The rent paid under a SLBT may even be related to affordability, rather than current market rents, because stepped and fixed rent negotiations in SLB cases are not an incentive, but rather a reflection of the price of capital raised by the seller. Grenadier (2005, p.1210-1211) discusses scenarios for sales pricing and rents including those for SLB in which

(1) "the seller would like to record a sales price that represents the maximum obtainable from a direct sale";

(2) that in which "the seller wishes to sell the property at the same price at which the property was purchased"; or

(3) the "seller is willing to pay the maximum standard rent ... to achieve a high selling price".

Wilson (1953) suggests that the lessor might charge a premium interest rate on the rental payment. This rental payment is amortised on the transaction price over the lease period based on the required return of the property, which is typically $3 / 8 \%$ to $1 \%$ higher than in a 
conventional loan arrangement. Although the investor caries absolute title of the property, Cary (1948) argues that in the event of tenant insolvency, the ownership prevents the stages required to obtain possession of mortgaged property, creating a greater risk than for a typical mortgage loan of equal size. Moreover, as a fundamental characteristic of property is illiquidity, the SLBT is less marketable than a loan. Since the SLBT has the advantage to the seller / lessee that the rental payments are fully tax-deductible, whereas with a loan only interest and not capital repayments are tax-deductible (Adams and Clarke, 1996), a rent above market levels may be mutually acceptable. The time taken to complete the SLBT would be longer than to arrange a bank loan as each deal is individually tailored. For these reasons, the SLBT price might be at a premium.

Wilson's theory is also consistent with Grönlund, Louko and Vaihekoski (2008) who argue that the SLBT price may be above the present value of future lease payments due to the lower risks, inexpensive costs of debt and a greater leverage ratio that the seller might benefit from. As a result, the rental payment in many cases might be above the market rent. A study on SLB in the Netherlands supports this theory, finding the contract rent in 275 SLB properties is usually higher than market rent (Hordijk, Rompelman and Koerhuis, 2010). One of the reasons given is the difference in the process for agreeing the rental level for a normal open market letting and a SLBT. In a normal open market letting the tenant will negotiate with the landlord to pay the lowest possible rent to the landlord. In a SLBT there is an incentive for the tenant to pay a high rent because they obtain a higher price on sale and leaseback (Valachi, 2009). If the rent is fixed at a level higher than the market level, then the amount of rental growth between the purchase date and the first rent review will be less than for the same property let at the market rent. In effect the purchaser is paying for rental growth prior to it happening. In other words, they are possibly overpaying for the property as the rent is artificially above the market level. 
Although the SLBT discount rate is higher than for a mortgage loan, the SLBT rate of return may underperform compared to non-SLBT, reflecting a low yield investment. This is because leaseback arrangements are regarded as a relative safe investment due to their guaranteed rental income (Cary, 1948; Wilson, 1953; Ling, 2012; JLL, 2015). This lower yield is consequently associated with a higher price compared with arms-length transactions assuming market rent. A study by Sirmans and Slade (2010) in the USA shows that SLB properties sell at $13.8 \%$ premium compared with non-SLB properties. Although this study did not seek the impact of SLBT on investor return, the transactions were found to be efficiently priced, with neither investor nor vendor obtaining excessive benefit. However, as previously mentioned, this condition of low yield also depends on the financial strength of the lessee. Since the higher the credit profile, the lesser the risk of rental default, this might enable the seller to persuade potential investors to accept a lower yield.

This yield used for this analysis is the net initial yield, which is the net operating income in the first year divided by the purchase price. It is a measure of market pricing at that particular time point, reflecting buyer perspectives on the risk and growth prospects associated with that asset. 


\section{Methodology}

\section{Price and Yield Differentials between Sale and Leaseback and non - Sale and Leaseback Transactions}

The purpose of this study is to analyse the impact of SLB on sale prices and net initial yields. This is achieved using quantitative methods. The empirical data is collected from CoStar and Estates Gazette Interactive (EGI), and comprises individual transactions sold in the UK between from 01 January 2005 to 31 March $2017^{1}$. The key requirements for data are as follows: (1) Transaction price; (2) Annual Net Operating Income (achieved annual rent); (3) Net Initial Yield (NIY) and; (4) Hedonic characteristics which influence capital and rental value, such as: building age, quality, location, rentable space, and property sector. To examine the impact on sale price and yield of SLBT, independent-samples t-tests and hedonic regression modelling are undertaken.

Sirmans and Slade (2010) assert that if a price difference occurs for properties with the SLB arrangement, an investor who pays a premium does so in the expectation of reaping riskadjusted higher value from a SLBT than non-SLBT. Therefore, for a SLB price premium to occur, the benefits from SLBT need to exceed the benefits from a comparable simple asset transaction not involving SLB. Thus, investors (in theory) calculate the benefit of the SLBT versus non-SLBT by assessing whether the present value (PV) of the Net Operating Income (NOI) received from the lessee in the SLBT plus the PV depreciated tax benefits related to the transaction are greater than the PV of the NOI and tax benefits from a non-SLBT. If this difference occurs, then competition between investors should result in a price premium on

\footnotetext{
${ }^{1}$ This coincides with the triggering of Article 50 (on $29^{\text {th }}$ March 2017), the process by which the United Kingdom (supposedly) committed to leave the European Union two years later.
} 
SLBT. However, assuming that the tax benefits are similar for both SLBT and non-SLBT, the price differential could only arise if there were differences in the lease payments (LPMT) and risk or discount rate $\left\{g_{b}\right\}$ with the following condition (Sirmans and Slade, 2010):

\section{LPMTSLB $_{S \text { LPMT }_{\text {NONSLB }}}$}

$\mathrm{g}_{\mathrm{b}, \mathrm{SLB}}<\mathrm{g}_{\mathrm{b}, \mathrm{NONSLB}}$

\section{Equation 1. Explanation for expected SLB Price and Yield Differential}

Assuming market rents, the hypothesis is that the expected cash flows of SLBT will be greater because SLB is by nature a low-risk investment due to the long-term secure income which reduces the risk of vacancy during the period. Additionally, the credit rating of the tenant is typically higher than for non-SLBT, thus lowering risk (Sirmans and Slade, 2010). According to risk / return profile theory (Baum and Hartzell, 2012), the discount rate or the return will be lower for SLBT than for regular investment transactions as the risk premium is considered low for SLBT.

\section{Hedonic Regression Method}

Since this research aims to build on that of Sirmans and Slade (2010), hedonic regressions are performed with dependent variables (1) Sale Price, (2) Sale Price per sq. ft, and (3) Net Initial Yield (NIY). The first of these is the hedonic model of SLB developed by Sirmans and Slade, which examines only the SLB price premium effect, and does not consider the yield of the investment. The results of this are perhaps of most interest to corporate occupiers who are considering selling and leasing back properties they own, as it gives an indication of any price premium they might expect to receive compared with market prices. The third regression, which looks at the initial yield discount that SLB might achieve, is perhaps of most interest to investors, as it relates to the perceived riskiness of the investment. Each dependent variable is regressed on several independent variables: the size and age of the building, type of property, 
location, and dummy variables representing the SLB factor, the timing of each transaction and the quality of the property, proxied by its CoStar Star Rating. The full regression models are shown in Equations 2, 3 and 4. Variants of each model are assessed to explore the impact of the explanatory variables.

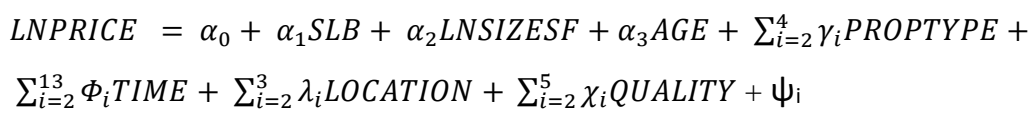

Equation 2. Hedonic Regression Model for Sale Price as Dependent Variable

$$
\begin{aligned}
& \text { LNPSF }=\alpha_{0}+\alpha_{1} S L B+\alpha_{2} L N S I Z E S F+\alpha_{3} A G E+\sum_{i=2}^{4} \gamma_{i} P R O P T Y P E+ \\
& \sum_{i=2}^{13} \Phi_{i} T I M E+\sum_{i=2}^{3} \lambda_{i} L O C A T I O N+\sum_{i=2}^{5} \chi_{i} Q U A L I T Y+\psi_{i}
\end{aligned}
$$

Equation 3. Hedonic Regression Model for Sale Price per sq. ft as Dependent Variable

$$
\begin{aligned}
& N I Y=\alpha_{0}+\alpha_{1} S L B+\alpha_{2} L N S I Z E S F+\alpha_{3} A G E+\sum_{i=2}^{4} \gamma_{i} P R O P T Y P E+\sum_{i=2}^{13} \Phi_{i} T I M E+ \\
& \sum_{i=2}^{3} \lambda_{i} L O C A T I O N+\sum_{i=2}^{5} \chi_{i} Q U A L I T Y+\psi_{i}
\end{aligned}
$$

Equation 4. Hedonic Regression Model for Net Initial Yield as Dependent Variable

\section{Description of Variables}

LNPRICE = Natural log of sales price. The transformation is applied because selling prices vary widely, particularly in a large sample dataset. This transformation provides less weight to extremely high values, such as property transaction price (Tabachnick and Fidell, 2013). Besides mitigating the effects of extreme values, the transformation into natural logarithm creates a more normal distribution of data which allows us to interpret the coefficients regarding the average percentage premiums (de Leeuw, 1993).

NIY = Net Initial Yield (\%) is the net operating income in the first year of ownership, divided by the purchase price.

$S L B=$ = A binary variable for SLB status of the transaction (= 1 if SLBT, 0 for nonSLBT);

LNSIZESF $\quad=$ The natural log of the square footage of building area being transacted 
PROPTYPE = Property type comprising office, industrial, retail and another commercial sectors. Other commercial includes leisure, hospitality and healthcare. Each property type is included in the structural model as a binary variable, except "other commercial', which is the reference category.

LOCATION = Location of each transaction, based on the MSCI PAS classification: London, South East UK and Rest of UK. Each category is included in the structural model as a binary variable, except Rest of the UK, the reference category.

TIME = Year of Sale, represented by annual time dummies from 2005 through 2017. Each annual period is included in the structural model as a binary variable, except 2005, the reference category.

QUALITY = CoStar Star Rating of property. This variable was not included in the work of Sirmans and Slade (2010) but is recommended to be used when considering determinants of property price by Crosby, Jackson and Orr (2016). The Star Rating is included in the structural model as a binary variable. The reference category is 1 -Star properties.

LNPSF = Natural log of price per sq. ft. Used as dependent variable (Equation 3) to check whether a SLB premium exists when the size of properties is accounted for.

$\alpha, \gamma, \phi, \lambda$ and $\chi=$ coefficients of the characteristics and dummies

$\Psi \quad=$ random error term

The main independent variable of interest for this analysis is the Sale and Leaseback factor.

Following the theory of Sirmans and Slade (2010), for the sale price and price psf models the coefficient on SLB is expected to be positive if the rental revenue (NOI) of SLBT is higher or the discount rate (proxied by NIY) is lower compared to a single asset sale that does not involve SLB. If the sign of the SLB coefficient is positive, this implies that SLB transactions occur at a premium price compared with normal transactions.

With the NIY hedonic model, the coefficient of SLB would be expected to be negative, as the risk in investing in SLBT should be lower due to its secure income stream, supporting the hypothesis that SLB transactions occur at a lower return compared to non-SLB transactions. 


\section{Data}

The data used for this analysis was gathered through CoStar and EGI, supplemented by company news announcements and consultant reports. It comprises individual unit sales transactions in the UK between 01 January 2005 to 31 March 2017 for which net initial yield and sale price information is available.

For the SLB transactions the number of transactions for which both price and yield is available is 357 deals (21.99\% of the total sample). Of these 357 SLB deals the sectors are distributed: 127 for offices, 122 for industrial, 73 for retail, 12 for hospitality, 8 for health care, and 15 for leisure sectors.

The non-SLBT data was also gathered from CoStar using the same criteria as for SLBT and comprise individual unit sales transactions for which yield and sale price information is available. Based on these criteria, the sample of individual non-SLBT transactions comprises 1266 deals $(78.01 \%$ of the total sample).

Of the 357 transactions in the SLB sample, the office sector was the most active during the research period (35.6\% of the sample), which is consistent with Colliers' (2014) report on SLBTs. This proportion is similar to the industrial sector, which comprises $34.2 \%$ of the SLBT sample. This is unsurprising, because of growing investor interest in industrial properties arising from the recent growth in e-commerce (BNP Paribas Real Estate, 2016). Retailers (about $20.4 \%$ of the total sample) have deployed a SLB strategy for many years. Nevertheless, the non-SLB sample comprises a substantially higher proportion of retail property than the SLB sample.

To assess whether SLB and non-SLB properties are of comparable quality, the star-rating of 
the properties was compared ${ }^{2}$. Around $60 \%$ of the properties in both sub-samples are rated 3Star and fewer than $1 \%$ are rated 1-Star, A higher proportion of the SLB properties are rated 4 and 5-Star. This is taken into account in the regression analysis by using dummy variables for the star-rating categories.

The majority of the transactions (73.3\%) occurred during 2012-2017Q1. This is in line with JLL (2015), which reported that 2014 was the period with the highest number of corporate disposals of real estate in the European market, including the UK, since 2007. Another reasonable explanation is the low interest rate during the recovery cycle (post credit crunch in 2007-2009) and thus greater availability of capital during this time (JLL, 2015).

Table 2 gives the Descriptive Statistics for the full sample of properties (Panel A) and for the two sub-samples (SLB and non-SLB - Panel B). Panel C shows the mean sub-sample values for several of the variables of interest to this research, for the three largest property sectors.

\section{INSERT TABLE 2 HERE}

Panel A shows that the sale price for the total sample varies from $£ 9,000$ to $£ 1,090,000,000$, with the transactions covering all the counties and regions in the UK over a 12 years' period. The lowest sale price was a retail unit transaction in Glasgow through an auction sale and the highest was the HSBC building transaction at Canary Wharf, London. The lowest priced property had a Net Initial Yield of 7\% while the HSBC building had a NIY of 3.8\%.

\footnotetext{
${ }^{2}$ This information is available for 149 of the SLB properties and for 1265 of the non-SLB properties
} 
In Panels B and C, the statistical significance of t-test results for the differences in the mean values of the variables is highlighted using asterisks. From this, it is apparent that there are statistically highly significant differences in the mean values of two of the dependent variables of interest, Sale Price and Net Initial Yield. The mean sale price for the SLB sample is 4.41 times that of the non-SLB sample, while the mean net initial yield achieved by SLB is 1.83 percentage points lower than for non-SLB properties. This result is consistent with the mean annual Net Operating Income (NOI) for the SLB properties which is 3.8 times that of the nonSLB properties.

As Table 2 shows, there are also significant differences between the groups for some of the other characteristics of the sample properties. The mean building size for SLBT is 3.4 times that of the non-SLBT, perhaps because assets disposed of by SLB are typically large compared to non-SLB properties to make these complicated deals worthwhile (Grönlund, Louko and Vaihekoski, 2008). Additionally, the average building age is quite high, at about 59 years, with the average age of SLBT properties being twenty years less than for non-SLBT. These mean values may be skewed by the presence of five non-SLB properties older than 200 years, whereas only one SLB property is this old.

Although the physical characteristics are quite different, and the maximum and minimum sales price differ considerably, the mean sale price per SF at $£ 281.28$ (SLBT) and $£ 272.61$ (nonSLBT) is similar. The average rent per SF is $£ 1.08$ (6.59\%) higher for non-SLBT than for SLBT, which is perhaps unexpected, but can be explained by the disparity in building size, and by the differences in sector composition between the samples.

From Panel C it is apparent that the greatest disparities between the SLB and non-SLB samples occur in the Office sector. The trends observed for the full sample are demonstrated within the sector samples too - higher sale price and lower net initial yield. This table also 
shows that the Retail sample contains the oldest properties and the Industrial sector contains the newest, on average.

Independent samples t-tests year by year reveal that the mean sale prices are higher for the SLB sample, although the difference is not always statistically significant, because of the relatively small number of SLB transactions each year. However, the difference in Net Initial Yield is highly statistically significant from 2012 onwards, and is consistently around $2 \%$ to $2.5 \%$ lower for the SLB sample than for the non-SLB sample. This is shown graphically in Figure 1, which also shows the mean annual Government 10-Year Bond Yields, which were derived from Bank of England (2018) data. Such bonds are considered almost free from risk, and are typically used to assess risk premia demanded by investors. Thus, from these samples of SLB and nonSLB transactions, SLBTs achieve a net initial yield approximately 4.5 percentage points above the Government Bond Yield while non-SLBTs achieve a premium of around 6.75 percentage points compared with this risk-free rate.

\section{INSERT FIGURE 2 HERE}

To assess whether this difference in Yield is attributable to property sector differences between the samples, the mean annual net initial yield was plotted by sector (see Figure 2), with the smaller sectors (leisure, hospitality and healthcare) being combined as "other commercial". From these, it can be seen that the yields for office and industrial properties are generally decreasing over time, whereas for retail and the small "other commercial" sample, the pattern is less clear. Nevertheless, the trends in yields for SLB and non-SLB properties are similar, with yields for SLB properties in all sectors being between $1-3 \%$ below those for the nonSLB samples.

Insert Figure 2 here 


\section{Comparison of mean values for the variables in the SLB and non-SLB samples}

Following Equation 1 the independent samples t-test is undertaken to check how the price and net initial yields of SLBT compare to non-SLBT. This tests whether there is a statistically significant difference in the mean scores for the two groups (Pallant, 2010), including checking whether the variances of the two groups are equal. Differences in mean values are displayed graphically for the property sectors (retail, office, industrial and other commercial), and a comparison with Government 10-Year Bond Yields is made, to highlight the risk premium required by property investors.

\section{Hedonic Regression Analysis}

To explain further the impact of sale and leaseback on the sale price and net initial yield of commercial properties in the UK, several regression models were estimated. The main purpose is to isolate the impact of the key variable of interest: the SLB dummy variable. However, the regressions also enable the effects of other explanatory variables, which may be confounding factors, to be examined. Sale prices and yields depend on many factors, including sector, location, building specification, tenant covenant strength, lease length etc, as well as risk premia and returns available from other asset classes. The analysis was performed using SPSS which does not provide procedures to test and control for heteroskedasticity by default. Therefore the syntax created by Daryanto (2019) and by Hayes (Hayes and Cai, 2007) was incorporated to perform the Breusch-Pagan and Koenker tests to ensure robust standard errors were applied. Tests for multicollinearity give low variance inflation factors ${ }^{3}$.

\footnotetext{
${ }^{3}$ (VIF values are substantially below 10 apart from the dummy variables for 2015 and 2016 for which VIF is 10.3 and 10.4).
} 


\section{Sale Price Hedonic Models}

The results of the regressions based on Equation 2, with dependent variable ln (Sale Price), are shown in Table 3. The first model contains size and age explanatory variables, and dummy variables for property quality (Star Rating), sector and year of transaction. The model has a high adjusted $\mathrm{R}^{2}$ of 0.854 which means that the independent (predictor) variables explain $85.4 \%$ of the variance in the (natural log of) property price. This model explains sale price reasonably well, and attains statistical significance $\left(\mathrm{f}_{(25,1597)}=374, \mathrm{p}=0.00\right)$. The regression result shows positive coefficients for the SLB variable of 0.201 with $p$-value $0.003(p<0.01)$, hence the SLB factor is making a highly significant contribution to the model. Furthermore, from the coefficient it can be deduced that the SLBT occurs at a $22.3 \%$ premium to non-SLBT ${ }^{4}$, a substantial effect. To ensure that the results were not distorted by the most expensive building, the regressions were also run omitting the HSBC Canary Wharf transaction, which altered the SLB coefficient by only $0.1 \%$. Therefore, we can reject the null hypothesis of no effect and infer that SLBT has a positive impact on the sale price. This is a larger effect than was found by Sirmans and Slade's (2010) analysis of SLBT in the USA, which found that SLBT occurs at $13.86 \%$ higher relative to non-SLB properties. However, that research used a smaller sample of only 163 SLB properties, and did not incorporate property quality as an explanatory variable.

As discussed previously, explanations for the price premium for SLB properties include the fact that the properties have a tenant in place and the lower risk of void periods. Additionally, as discussed earlier (Grenadier, 2005; Valachi, 2009), companies may wish to maximise the

\footnotetext{
${ }^{4}$ The coefficient on the SLBT variable can be converted into the percentage price increase by using the formula PERCENT INCREASE $=100 *\left[e^{0.201}-1\right]$ or $22.3 \%$ (Halvorsen and Palmquist, 1980)
} 
price they receive for their property even though this will require higher rental payments. A further potential explanation is that the vendor may have to pay a property sales tax, Capital Gains Tax in the UK, and thus will require a premium price to offset this and make SLB worthwhile.

Considering the other independent variables, the size of the building has a large positive, statistically highly significant coefficient (0.902), as would be expected. Perhaps surprisingly, the age variable has a (very small) positive value, indicating that older properties might transact at a higher price. The older properties might be situated in superior locations, and buildings older than 70 years might be considered 'vintage' and thus transact at a higher price (Fuerst and McAllister, 2011). Property age was only available for 901 of the 1623 properties. Rerunning the regressions without this variable altered coefficients by less than $1 \%$ in all cases.

The location and property sector variables also contribute to the model's explanatory power. The coefficients of PROPTYPE shows "other commercial properties" (the reference category) transacted at a premium compared with retail, office and industrial properties, with industrial properties transacting at a lower price than the other sectors. The common explanation is that industrial properties tend to be located in suburbs, which command lower prices than the city centre (McDonald and McMillen, 2011). However, the growth of the industrial sector has been strong in the past five years owing to the rise in e-commerce, so industrial properties such as logistics warehouses and factories might increase in value at a faster rate than property in other sectors.

As would be expected, properties in the South East and London transacted at a premium compared with properties in the rest of the UK (the reference category). London has perennially been in the top five Global Financial Centres and therefore has always been a preferred location for property investment when compared to the rest of the UK (CDI and 
Z/Yen, 2017).

The coefficients on the Star Rating dummy variables exhibit pricing effects that would be expected. Compared with the 1-Star reference category, prices increase as the Star Rating increases. As mentioned previously, most of the properties are 2- and 3-Star. Only the premiums for 4-Star and 5-Star properties are statistically significant.

The year of transaction dummy variables, with 2005 as the reference category, show that peak prices occurred in 2007, just before the Global Financial Crisis, but the coefficients are not statistically significant.

Since most of the transactions in this dataset occurred after 2011, Model (2) restricts the sample to the period 2012 onwards, with little impact on the sign or magnitude of all coefficients, although the price premium of SLB increases to $24.5 \%$ $\left(\left(\mathrm{e}^{0.219}-1\right)^{*} 100\right)$.

Models (3), (4) and (5) explore the sectors separately. Comparing sectors, one notable difference is that the SLB dummy variable, whilst remaining positive, now has a nonsignificant coefficient for retail and industrial properties. The regression implies that the hypothesis of no price premium for SLB in the retail and industrial sectors cannot be rejected. The apparent difference that was found using the independent samples t-test might be accounted for by the other explanatory variables in the regression - size, location, quality and year of transaction, or the lack of statistical significance might arise as a result of differences in sample composition. Retail comprises over half of the non-SLBTs but only about one-fifth of the SLB sample.

For office properties, the SLB factor remains positive and statistically significant, and translates into a premium of $32.3 \%$. This is patently a very large apparent premium, and the 
coefficients are likely to be biased by omitted variables in the regressions, as discussed earlier.

This is examined further in Section 6.

\section{INSERT TABLE 3 HERE}

\section{INSERT TABLE 4 HERE}

To assess whether the size disparity between the SLB and non-SLB samples might be biasing the results of the sale price premium, additional regressions were performed using the same independent variables as in Models $1-5$ in Table 3, but this time using ln (Price per sf) as the dependent variable (see Equation 3). The results of these regressions are given in Table 4, and show that SLB properties achieve a premium per sq. $\mathrm{ft}$ of $22.0 \%$ (full sample); $24.2 \%$ (full sample 2012 onwards); $14.3 \%$ (Retail); 32.3\% (Office) and 10.6\% (Industrial). The price per square foot premia for the individual sectors are the same as for the Sale Price premia. All of these are statistically significant apart from the Retail and Industrial Sectors separately.

\section{Net Initial Yield Hedonic Models}

The results of the NIY models, based on Equation 4 are shown in Table 5. The adjusted $R^{2}$ is considerably lower for these models, explaining only around $20-30 \%$ of the variability in Net Initial Yield. This is to be expected because of omitted variables in these regressions, such as the respective tenant's strength of covenant, lease term and reversionary yield, as well as detailed information about the physical condition and design of the property (Fisher, 1930; Lam \& Tipping, 2016). Brunie (1960) argues that the credit profile of the tenant is the most influential factor affecting the discount rate. An investor is likely to agree to a SLBT only if due diligence indicates the seller has a low risk of defaulting on rent, yet one reason a company 
might engage in SLBT is because they are unable to obtain further credit from other sources.

The effect of covenant strength and lease length is investigated in Section 6.

The coefficients in the NIY models appear plausible and are generally consistent with the majority of prior expectations. The statistically significant variables are the SLB dummy variable, several of the Quality (Star Rating) variables, the OFFICE and INDUSTRIAL sector coefficients, the London and South East location dummy variables and several of the YEAR dummy variables. In Model (1), the coefficient on the SLB factor is negative with the value of 1.693, meaning that, all else being equal, SLB properties transact at a net initial yield 1.7 percentage points below the yield of non-SLB properties. This can be interpreted as the NIY of SLBT being $18.3 \%$ lower than for non-SLBT (the percentage reduction on the intercept). As previously discussed, the SLB arrangement attracts lower yields because of reduced risk resulting from the secure and predictable income stream, as suggested by Valachi (2009). This outcome supports the Sale Price Model result, and therefore this analysis rejects the null hypothesis of no effect and accepts that SLBT has a lower return compared to the normal investments.

Considering the other independent variables, an increase in building size results in a small reduction in NIY, and building age appears not to have a substantial effect on NIY. Regarding sector, compared with "other commercial" properties, office properties transact at a statistically significant 1.2-1.4 percentage point higher yield, and industrial and retail properties also appear to transact at a higher yield, albeit the difference with these "other commercial" sectors is not statistically significant for retail properties. "Other commercial" includes healthcare, hospitality, leisure, as well as sports and entertainment. This category is quite diverse: the hospitality sector often achieves a low yield, depending on the vacancy and operator, while healthcare might achieve a higher yield. This is evident in UK healthcare property returns in 
2016 for example, which, at $7.9 \%$, are higher than other contemporaneous property investments (MSCI, 2017).

The results for property located in London or in the South East reveal a statistically significant reduction in yield, implying that investment in these geographical areas is considered to carry lower risk. The trend in the Star Ratings is as expected, with initial yields decreasing as Star Rating increases. Finally, compared to the reference category of year 2005, there is some change in the NIY over time, with the highest yields occurring in 2012 and 2013, but for most years the coefficients are not statistically significant.

Restricting the sample to 2012 onwards (Model 2), the SLB factor now has a coefficient of 1.879, meaning that SLBTs occur at a yield of 1.9 percentage points lower, a value very close to the NIY discounts found in the t-tests and graphs of Section 4.1. The coefficients on the YEAR dummy variables now become statistically significant and show a trend of yield reduction year-by-year.

When considering the regressions for the three main commercial property sectors separately (Models 3-5), the SLB factor is highly statistically significant in all cases, and translates into a net initial yield reduction of 2.2 percentage points for Retail, 1.7 percentage points for Offices and 1.9 percentage points for Industrial properties, again supporting the findings of Section 4. In summary, landlords appear willing to pay a substantial premium for SLB properties, and investors seem willing to accept a lower yield than for arms-length transactions that do not involve sale and leaseback. The price premium of at least $20 \%$ for the properties in this sample appears to be higher than the $14 \%$ reported by Sirmans and Slade (2010).

The Net Initial Yield was found to be around 2 percentage points lower for SLBTs than for non-SLBTs, using various methods of analysis. This appears to hold for all sectors. 
Comparison with Government 10-Year Bond Yields reveals that for these samples of SLB and non-SLB transactions, SLBTs achieve a net initial yield approximately $4.5 \%$ above the riskfree rate, while non-SLBTs achieve a premium of around $6.75 \%$.

The results of this empirical analysis have fulfilled the condition of Equation 1, $\mathrm{g}_{\mathrm{b}, \mathrm{SLB}}<$ $\mathrm{g}_{\mathrm{b}, \mathrm{NONSLB}}$ (proxied by the implicit discount rate or yield), and therefore support the hypotheses that there is a SLB price premium and that it corresponds with a lower discount rate.

\section{INSERT TABLE 5 HERE}

\section{Explaining the Results by considering lease length and covenant strength}

The results of the hedonic regression model reveal a significant price premium paid for SLB properties, while accounting for the heterogeneity of property characteristics, such as location, size and quality. However, as discussed, lease lengths and tenant covenant strength are also key factors that can influence the price and yield of transactions. The typically longer lease lengths of SLBs (Hutchison, Adair and Findlay, 2011) and stronger covenants of SLB occupiers (Sirmans and Slade, 2010), in addition to favourable loan structures of SLBTs, could also contribute to price premiums.

Using CoStar, lease length data for 201 SLB deals and 220 non-SLB deals was obtained and Weighted Average Unexpired Lease Term to expiry of investment space, weighted by occupied floorspace, was calculated. Raw WAULT data was categorised into Short (less than 60 months), Medium (60 to 120 months), Long (120 to 240 months) or Very Long (more than 240 months).

Data on ex ante tenant covenant strength for the year of transaction was searched using historical marketing brochures on CoStar and various Financial Analysis Reports. This allowed tenant covenant strength data for 64 SLB deals and 119 non-SLB deals to be gathered. For SLB properties, covenant strength of the seller was used, while for non-SLB properties, covenant 
strength of the existing tenant was used. In non-SLB properties with two tenants, the average credit score was used, and in those with three or more tenants, a 'Medium Risk' rating was given to the property. Covenant strength sources included D\&B (76.5\%), Experian (4.9\%), CreditSafe (2.2\%), S\&P (1.6\%), ICC (0.5\%) and Qui (0.5\%) (the remainder being multi-tenanted properties with a 'Medium Risk' rating). They were recoded into Very High Risk, High Risk, Medium Risk, Low Risk, or Very Low Risk based on interpretation guidelines from the respective rating companies. ${ }^{5}$ (See Table 6).

\section{INSERT TABLE 6 HERE}

Hedonic regressions with heteroscedasticity-robust standard errors were performed with dependent variables (1) Sale Price, (2) Sale Price per sq. ft, and (3) Net Initial Yield (NIY). Since this section aims to focus on the impact of lease lengths and tenant covenant strength, these two factors are included as additional independent variables. The results of the regressions are given in Table $7^{6}$.

\section{INSERT TABLE 7 HERE}

${ }^{5}$ https://www.dnb.com.lv/en/rating.html;

https://www.standardandpoors.com/en_US/web/guest/article/-/view/sourceId/504352

${ }^{6}$ Other variants of the regressions were also performed, the results of which are available from the author upon request. These include restricting the sample to those transactions for which all fields of data were available. In each case, the coefficient on the SLB dummy variable was no longer significant in explaining sale price and was substantially reduced in explaining NIY compared with regressions without WAULT and covenant strength data. 
From Table 7 it can be seen that the sale price model has high explanatory power, and that the SLB variable in the regression still has a slightly positive coefficient of 0.042 , but this is no longer statistically significant, with a p-value of 0.611 (>0.01). This increase in p-value is consistent with expectations that lease length and covenant strength are key contributors to the price premium enjoyed by SLB properties, such that once these factors are controlled for, the SLB variable no longer accounts for a significant amount of variance in property price. Nonetheless, the SLB variable may remain positive due to other less influential factors associated with SLB price premiums, such as a beneficial loan structure for purchasers.

The coefficients of lease length and covenant strength variables are also consistent with expectations. The coefficients of lease length variables increase along from Medium (0.169) to Long (0.178) to Very Long (0.370), suggesting that longer unexpired lease lengths will fetch greater price premiums. Similarly, the coefficients of covenant strength variables increase from High Risk (-0.403) to Medium Risk (-0.014) to Low Risk (0.009) to Very Low Risk (0.144). This shows that purchasers are willing to pay higher price premiums for more established tenants. Notably, properties with Very Low Risk tenants enjoy a price premium of $15.5 \%$, while properties with High Risk tenants suffer a price discount of $33.2 \%$, albeit based on a very small sample. This suggests that the presence of anchor tenants or high-risk tenants could have a substantial impact on transaction prices.

The results of the regression for price per sq. $\mathrm{ft}$ are very similar, and consistent with the findings above.

The results of the NIY model show that the adjusted $\mathrm{R}^{2}$ is slightly higher than in the original model, at 0.253 , suggesting that these variables account for $25.3 \%$ of the variance in NIY. This could be due to other transaction-specific factors that can impact NIY more substantially than sale price, such as the specific lease conditions surrounding rent (e.g. rent-free periods, rent reviews, etc.) or the purpose of non-SLB deals, e.g. for redevelopment sales, lower WAULTs 
may be preferred. The coefficients in the NIY models are consistent with expectations. The SLB coefficient remains negative at -1.020 ( 0.073 higher than the original SLB coefficient) and is statistically significant at $\mathrm{p}$-value $<0.001$. The less negative SLB coefficient again reflects the explanatory power of lease length and covenant strength factors in assessing SLB impact on lower yields.

The coefficients of lease length variables appear to be generally consistent with expectations, with properties having Very Long leases tending to reduce yields most substantially $(-1.03 \%)$. However, the coefficient on Long leases is slightly positive (0.047), suggesting properties with Long leases tend to have increased yields. This could be due to the confounding effect of long leases having open market rent (as opposed to shorter or very long leases that occur with a rental discount).

Finally, the coefficients of covenant strength variables are consistent with expectations, with properties having less risky occupiers achieving greater yield discounts. The coefficients increase from Very Low risk (-0.323), to Low risk (-0.101), to Medium risk (0.286) to High risk (0.688), suggesting that purchasers are willing to pay higher premiums and hence achieve lower yields for properties with credit-worthy occupiers, and vice-versa. Again, it is notable that properties with Very Low risk occupiers achieve a $0.323 \%$ decrease in NIY while those with High risk occupiers have a $0.688 \%$ increase in NIY, suggesting the substantial impact of anchor tenants and risky tenants on NIY figures.

Figures 3 and 4 illustrate the impact of lease length and credit rating on sale price and net initial yield for the retail, office and industrial samples separately. The mean sale price and NIY for the SLB properties is compared with non-SLB properties of varying WAULT and tenant credit scores. From these, it can be seen that the sale price tends to remain higher and the NIY remains lower, even when the non-SLB properties have long WAULT and tenants with high credit 
ratings. Performing independent samples t-tests, the differences between the SLB and the nonSLB samples are mostly statistically significant, at least at the $10 \%$ level.

\section{INSERT FIGURE 3 HERE}

\section{INSERT FIGURE 4 HERE}

In summary, the change in SLB coefficients upon controlling for lease length and covenant strength suggest that these variables provide substantial explanation for the price premiums and yield discounts achieved by SLB transactions, but do not fully account for the disparities. Nevertheless, the trends of the coefficients on these variables conform to expectations, with longer unexpired lease terms and less risky tenants generally fetching greater price premiums and yield discounts.

\section{Summary and Conclusions}

Sale and leaseback transactions have increased in popularity since the 1970s, and many corporations have deployed this strategy for capital raising. Earlier research has focused on the SLB impact on share price for the seller-lessee; however, few studies have examined the investor's motive, particularly the price paid and the return achieved. This paper has examined the impact of the sale and leaseback arrangement on commercial real estate transactions within the UK from 2005 to the first quarter of 2017. It will help companies assess what might be a fair price they should receive if they were to sell the properties they own to a landlord and to lease them back. Equivalently, it should help landlords to assess what sort of premium would be reasonable to pay for a SLBT, and what sort of reduction in yield it would be appropriate for investors to accept.

The empirical findings support the hypothesis that SLB in commercial properties has an impact on sale price and returns. Sale prices ostensibly tend to be at a premium of at least $20 \%$ 
compared with standard arm's length transactions, and the Net Initial Yield is around 2 percentage points lower, regardless of sector. Both effects are statistically significant. Sale price premium is greatest for the Office Sector, while Industrial properties appear to show only a small premium. A price premium and yield discount are still present when lease length and tenant credit rating are accounted for, but the magnitude of the disparity is reduced.

The inference is that SLBTs are considered to carry particularly low risk because the tenant is already in place, and due diligence as part of the legal process should have ensured the creditworthiness of the seller. Although the actual lease terms will be individually negotiated, the buyer is likely to insist on a long lease to recoup the investment, and there may be specific terms in the contract such as the option for the seller to re-purchase the property at the end of the lease.

The analysis has several practical implications. From a vendor's perspective, the findings give an indication of the price premium they might expect to receive for their property compared with market prices for similar properties in a similar location. This will help them assess whether SLB is worthwhile compared with other financing options available to them. Although the seller might benefit from a premium price, there should not be a wide disparity between the actual value of the property to be sold and leased back. The property value should be supported by objective evidence, such as an appraisal by third parties. Nevertheless, the typical premium paid for such property, combined with knowledge that a purchaser should be willing to accept a lower yield, should assist with contract negotiations.

Similarly, for potential purchasers, knowledge of the order of magnitude of typical price premiums for SLBTs should help them calculate an appropriate offer price. They must bear in mind that the agreed rent should seek to reflect fair market value and not purely consist of an amortization of the acquisition price plus an interest rate. There are risks associated with the 
possibility of seller - lessee insolvency, but this risk is typically less than the risk of void periods when purchasing non-SLB properties. The findings of a yield reduction of around 1 $3 \%$ should help institutional investors compare SLB investment with alternative opportunities.

There are limitations to this research. Property transactions could only be included where individual sale prices were available (thereby excluding bulk portfolio sales) and where it was possible to calculate net initial yield. Each transaction is unique, and property has heterogeneous characteristics. Perfect data would include a series of transactions of properties of similar size and specification, situated next to each other and leased to the same tenant in the same year. Half of these properties would be sold as SLBTs and half as normal arm's length transactions, all on the same date, which is patently unrealistic.

This research has not taken into account specific tax implications. Differing tax regimes might affect the attractiveness of SLB as an option for a company wanting to raise capital. In particular, if capital gains tax is payable by the vendor, they might require a higher sales price to compensate for this, which might account for part of the price premium found in this research. However, from a landlord's perspective, whether they purchase a SLB property or engage in a non-SLB transaction, it should not affect the tax they pay, so should not distort the key findings of this research, that there is a sizable price premium and an Initial Yield reduction of around 2 percentage points for SLBTs.

The difficulty in obtaining accurate, comprehensive data which is in the public domain is widely recognized. A larger sample size would increase the reliability of the findings. As explained in Section 3, the data for this analysis comprises UK transactions up until the triggering of Article 50, the start of the process by which the United Kingdom leaves the European Union. A larger sample might be achieved by incorporating data from countries other than the UK. There may be privately held data available which would improve the quality of 
the data and add further support to the hypotheses of this analysis. Research could also be expanded to analyse portfolio transactions, as well as conducting analysis using a rent hedonic model, with results then being compared with average market rents.

\section{References}

Adams, A. T. and Clarke, R. T. (1996) 'Stock market reaction to sale and leaseback announcements in the UK', Journal of Property Research, 13(1), pp. 31-46. doi: $10.1080 / 095999196368862$.

Bank of England (2018) Monthly average yield from British Government Securities, 10-year Nominal Par Yield IUMAMNPY. Available at: https://www.bankofengland.co.uk (Accessed: 30 May 2018).

Barris, R. (2002) 'Sale-leasebacks move to the forefront: what is motivating buyers and sellers and what are their preferred methods', Briefings in Real Estate Finance, 2(2), pp. 103-112.

Baum, A. and Hartzell, D. (2012) Global Property Investment: Strategies, Structures, Decisions. Hoboken, NJ: Wiley-Blackwell.

BNP Paribas Real Estate (2016) 2016: The Year of The UK Regions. London.

Brunie, C. H. (1960) 'Sale-Leaseback Rates of Return', The Appraisal Journal, Vol 28 (October) pp. 501-504.

Bryan, A. B. (2003) 'The state of sale-leasebacks: What corporations can and should expect today’, Journal of Corporate Real Estate, 6(1), pp. 15-23. doi: 10.1108/14630010410812207.

Cary, W. L. (1949) 'Sale and Lease-back of Corporate Property', Harvard Business Review, 27 (March) pp. 151-164.

Cary, W. L. (1948) 'Corporate Financing Through the Sale and Lease-Back of Property: Business, Tax, and Policy Considerations’, Harvard Law Review, 62(1), pp. 1-41. doi: 10.1007/BF02296672.

CDI and Z/Yen (2017) The Global Financial Centres Index 21, Financial Centre Futures. 
Shanghai.

CoStar (2012a) Peugeot Parks Sale and Leaseback Deals.

CoStar (2012b) Tesco closes $£ 450 m$ UK supermarket CMBS. doi:

http://www.costar.co.uk/en/assets/news/2012/January/Tesco-prices-450m-UK-supermarket-

CMBS-/.

CoStar (2015) Travis Perkins completes £32.25m sale-and-leaseback, 17/11/2015.

CoStar (2016a) David Lloyd completes $£ 350 \mathrm{~m}$ sale-and-leaseback of 44 health clubs with M\&G Investments.

CoStar (2016b) NFU Mutual/Standard Life agree £51m Premier Inn sale-and-leasebacks.

Crosby, N., Jackson, C. and Orr, A. (2016) 'Refining the real estate pricing model', Journal of Property Research. Routledge, 33(4), pp. 332-358. doi: 10.1080/09599916.2016.1237539.

Devaney, S. and Lizieri, C. (2004) 'Sale and leaseback, asset outsourcing and capital market impacts', Journal of Corporate Real Estate, 6(2), pp. 118-132. doi:

10.1108/14630010410812298.

dun\&bradstreet (2018) A Guide to Dun \&amp; Bradstreet's Predictive Indicators UK \& Ireland, www.dnb.co.uk. Available at: www.dnb.co.uk (Accessed: 5 February 2019).

EGI (2017) Lloyds sells 85 branches, 13/01/2017.

Evans, M. (2013) 'Raising capital from real estate', Journal of Property Investment \& Finance, 31(3), pp. 220-222. doi: 10.1108/14635781311322193.

Ezzell, J. R. and Vora, P. P. (2001) 'Leasing versus purchasing: Direct evidence on a corporation's motivations for leasing and consequences of leasing', The Quarterly Review of Economics and Finance, 41(1), pp. 33-47. doi: 10.1016/S1062-9769(00)00060-0.

Fisher, I. (1930) 'The Theory of Interest', The Journal of Finance, 3(8), pp. 1409-1427. doi: 10.1068/a301409.

Fisher, L. M. (2004) 'The Wealth Effects of Sale and Leasebacks: New Evidence', Real Estate 
Economics, 32(4), pp. 619-643.

Fuerst, F. and McAllister, P. (2011) 'The impact of Energy Performance Certificates on the rental and capital values of commercial property assets', Energy Policy, 39(10), pp. 66086614.

Grenadier, S. R. (2005) 'An Equilibrium Analysis of Real Estate Leases', Journal of Business, 78(4), pp. 1173-1213.

Grönlund, T., Louko, A. and Vaihekoski, M. (2008) 'Corporate real estate sale and leaseback effect: Empirical evidence from Europe', European Financial Management, 14(4), pp. 820843. doi: 10.1111/j.1468-036X.2007.00417.x.

Halvorsen, R. and Palmquist, R. (1980) 'The Interpretation of Dummy Variables in Semilogarithmic Equations.', The American Ec, 70(3), pp. 474-475. doi: 10.1016/01651765(82)90119-7.

Hodge, S. L. (1986) 'Sale-Leasebacks : A Search for Economic Substance', Indiana Law Journal, 61(4), pp. 721-756.

Homburger, T. C. and Andre, G. R. (1989) 'Real Estate Sale and Leaseback Transactions and The Risk of Recharacterization in Bankruptcy Proceedings', Real Property, Probate and Trust Journal, 24(1), pp. 95-140.

Hordijk, A. C., Rompelman, D. and Koerhuis, L. (2010) 'Ten years of sale-and-leaseback transactions in The Netherlands', Journal of Corporate Real Estate, 12(1), pp. 26-32. doi: 10.1108/14630011011025898.

Hutchison, N., Adair, A. and McWilliam, J. (2008) 'Covenant strength in shopping centres: a diversified risk?', Journal of Property Investment and Finance, 25(4), pp. 329-341.

Hutchison, N. E., Adair, A. S. and Findlay, N. (2009) The Treatment of Covenant Strength by the UK Property Industry. London.

Hutchison, N. E., Adair, A. S. and Findlay, N. (2011) 'The impact of covenant strength on property pricing', Journal of Property Research, 28(2), pp. 167-188.

JLL (2015) Raising capital from real estate: Is now the time to sell? London. 
Lam, T. Y. . and Tipping, M. (2016) 'A case study of the investment yields of high street banks', Journal of Property Investment \& Finance, 34(5), pp. 521-534.

Lasfer, M. (2007) 'On the financial drivers and implications of leasing real estate assets: The Donaldsons-Lasfer's Curve', Journal of Corporate Real Estate, 9(2), pp. 72-96.

de Leeuw, F. (1993) 'A price index for new multifamily housing', Survey of Current Business, 73(2), pp. 33-42.

Ling, N. L. F. J. (2012) 'Analysis of Factors and the Impacts of Sale and Leaseback

Transaction', Procedia - Social and Behavioral Sciences, 36(June 2011), pp. 502-510. doi: 10.1016/j.sbspro.2012.03.055.

M\&G Investments (2014) M \& G Investment Acquires £ 173 . 4 Million Gala Bingo Portfolio.

McCarthy, J. H. (1989) 'New Real Estate Sale And Leaseback Accounting', Real Estate FInance, 5(4), pp. 89-92.

McClary, S. (2006) 'Don’t think big Mac, think McProperty’, Estates Gazette, (610), pp. 66-9. McDonald, J. F. and McMillen, D. P. (2011) Urban Economics and Real Estate. 2nd ed. Danvers: John Wiley \& Sons, Inc.

Moor Park Capital Partners (2013) Moor Park Capital Reopens Sale \& Leaseback Market with c.£ 700m Refinancing. London.

Morgan Pryce (2017) Lloyds Bank Branches, Sale and Leaseback Deals.

MSCI (2015) 'IPD Indexes and Benchmark Methodology Guide - June 2014'.

MSCI (2017) MSCI Our story - MSCI.

Pallant, J. (2010) SPSS Survival Manual. Edited by Fourth. Maidenhead: McGraw-Hill.

Pottinger, G., Dixon, T. and Marston, A. (2002) 'Occupational futures? Divesting real estate and corporate PFI', Property Management, 20(1), pp. 31-48. doi: 10.1108/02637470210418951.

RICS (2015) RICS Valuation - Professional Standards UK January 2014 (revised April 2015), 
Basis of Value. London. doi: 10.1016/j.aqpro.2013.07.003.

Rutherford, R. C. (1990) 'Empirical Evidence on Shareholder Value and the Sale-Leaseback of Corporate Real Estate', AREUEA Journal, 18(4), pp. 522-529.

Sirmans, C. and Slade, B. (2010) 'Sale-Leaseback Transactions: Price Premiums and Market Efficiency', Journal of Real Estate Research, 32(2), pp. 221-241.

Slovin, M. B., Sushka, M. E. and Polonchek, J. A. (1990) 'Corporate Sale-and-Leasebacks and Shareholder Wealth', The Journal of Finance, 45(1), pp. 289-299.

Tabachnick, B. G. and Fidell, L. S. (2013) Using Multivariate Statistics: Pearson New International Edition. 6th edn. Northridge: Pearson Education.

Thontteh, E. O. (2013) 'An Appraisal of the Extent of Market Maturity in Nigeria Property Market', IOSR Journal of Economics and Finance, 1(4), pp. 33-38. doi: 10.9790/59330143338.

Tipping, M. and Bullard, R. K. (2007) 'Sale-and-leaseback as a British real estate model', Journal of Corporate Real Estate, 9(4), pp. 205-217. doi: 10.1108/14630010710848458.

Torrey, W. W. (1954) 'What Price Sale-Leasebacks?', The Appraisal Journal, 22 (April), pp. 174-82.

Valachi, D. J. (2009) ‘Sale-leaseback solution’, Commercial Investment Real Estate.

Ward, C. et al. (2006) 'Pricing upwards-only rent review clauses', Journal of Property Valuation and Investment, 16(5), pp. 447-454.

Whittaker, C. (2008) 'Hotel operator motives in UK sale and leaseback/management-back transactions', International Journal of Hospitality Management, 27(4), pp. 641-648. doi: 10.1016/j.ijhm.2007.07.031.

Wilson, J. A. (1953) 'Sale and Lease-Back - A Re-Appraisal', Case Western Reserve Law Review, 4(4). 
Table 1: Examples of Sale and Leaseback Portfolio Transactions in the UK 2010-2017

\begin{tabular}{|l|l|l|l|l|}
\hline Date & Tenant & $\begin{array}{l}\text { Business } \\
\text { Sector }\end{array}$ & Unit & $\begin{array}{l}\text { Price } \\
\text { Million) }\end{array}$ \\
\hline $\begin{array}{l}\text { Q1 } \\
\text { 2017 }\end{array}$ & Lloyds bank & Banks & 44 & 40 \\
\hline $\begin{array}{l}\text { Q1 } \\
\text { 2016 }\end{array}$ & David Lloyd & Fitness chain & 44 & 350 \\
\hline $\begin{array}{l}\text { Q3 } \\
\text { 2015 }\end{array}$ & Travis Perkins & Builders & 19 & 32 \\
\hline $\begin{array}{l}\text { Q4 } \\
2014\end{array}$ & Gala Leisure Limited & Retail & 47 & 173 \\
\hline $\begin{array}{l}\text { Q1 } \\
2014\end{array}$ & Bannatyne Fitness & Fitness chain & 39 & 92 \\
\hline $\begin{array}{l}\text { Q4 } \\
2013\end{array}$ & Marston's & Retail & 202 & 90 \\
\hline $\begin{array}{l}\text { Q1 } \\
\text { 2013 }\end{array}$ & Spire Hospitals & Hospital & 12 & 700 \\
\hline $\begin{array}{l}\text { Q4 } \\
\text { 2012 }\end{array}$ & Whitbread & Hotel & 7 & 51 \\
\hline $\begin{array}{l}\text { Q4 } \\
2012\end{array}$ & Peugeot Citroën & Car showrooms & 9 & 30 \\
\hline $\begin{array}{l}\text { Q1 } \\
2011\end{array}$ & Tesco & Supermarket & 11 & 440 \\
\hline
\end{tabular}

Source: Data from CoStar (2012a, 2012b, 2015, 2016a, 2016b), except data for Lloyds from EGI (EGI, 2017), data for Bannatyne and Gala from M\&G Investments (2014) and data for Spire from Moor Park Capital Partners (2013). 
Table 2: Descriptive Statistics for the Full Sample (Panel A) and the separate sub-samples

(Panel B) and by Sector (Panel C)

\begin{tabular}{|lrrrr|}
\hline Variable & \multicolumn{1}{l}{ Mean } & Std. Deviation & Minimum & \multicolumn{1}{l|}{ Maximum } \\
Panel A: All Transactions & & & & \\
$(\mathrm{N}=1,623)$ & & & & \\
Sale Price (£) & $9,801,771$ & $45,957,205$ & 9,000 & $1,090,000,000$ \\
Net Initial Yield (\%) & 8.08 & 3.06 & 1.20 & 25.00 \\
Price Per SF (£) & 274.51 & 474.58 & 2.81 & $7,982.74$ \\
Annual NOI (£) & 572,929 & $2,372,636$ & 630 & $45,577,500$ \\
Rent Per SF (£) & 17.21 & 19.64 & 0.12 & 324.57 \\
Size (SF) & 45,541 & 160,327 & 192 & $2,462,955$ \\
Age (Years) (N=901) & 58.81 & 53.09 & 0.00 & 424.00 \\
\hline
\end{tabular}

\begin{tabular}{|c|c|c|c|c|c|}
\hline \multicolumn{2}{|l|}{ Variable } & Mean & $\begin{array}{l}\text { Std. } \\
\text { Deviation }\end{array}$ & Minimum & Maximum \\
\hline \multicolumn{6}{|c|}{ Panel B (SLB: N = 357 and non-SLB: $N=1266$ ) } \\
\hline \multirow[t]{2}{*}{ Sale Price $(£)^{\star \star \star}$} & SLBT & $24,704,504$ & $82,770,462$ & 62,500 & $1,090,000,000$ \\
\hline & NonSLBT & $5,599,265$ & $26,452,814$ & 9,000 & $410,000,000$ \\
\hline \multirow[t]{2}{*}{ Net Initial Yield (\%)* } & SLBT & 6.66 & 2.23 & 1.20 & 22.01 \\
\hline & NonSLBT & 8.49 & 3.14 & 1.42 & 25.00 \\
\hline \multirow[t]{2}{*}{ Price Per SF $(£)$} & SLBT & 281.28 & 395.82 & 2.81 & $5,056.75$ \\
\hline & NonSLBT & 272.61 & 494.65 & 3.02 & $7,982.74$ \\
\hline \multirow[t]{2}{*}{ Annual NOI $(£)^{* * *}$} & SLBT & $1,346,538$ & $3,965,158$ & 6,600 & $45,577,500$ \\
\hline & NonSLBT & 354,778 & $1,605,274$ & 630 & $29,069,000$ \\
\hline \multirow[t]{2}{*}{ Rent per SF $(£)$} & SLBT & 16.37 & 22.51 & 0.23 & 324.57 \\
\hline & NonSLBT & 17.45 & 18.76 & 0.12 & 254.61 \\
\hline \multirow[t]{2}{*}{ Size $(\mathrm{SF})^{\star * *}$} & SLBT & 101,091 & 173,206 & 600 & $1,099,995$ \\
\hline & NonSLBT & 29,877 & 152,970 & 192 & $2,462,955$ \\
\hline \multirow{2}{*}{$\begin{array}{l}\text { Age (years) }{ }^{* * *} \\
(N=138 \text { and } 763)\end{array}$} & SLBT & 41.46 & 42.69 & 0.000 & 227.00 \\
\hline & NonSLBT & 61.95 & 54.20 & 0.000 & 424.00 \\
\hline
\end{tabular}

*** Denotes a statistically significant difference between the means of the respective variables at the $1 \%$ level, and incorporates the results of the Levene's test to assess whether the variances of the two groups are equal. 


\begin{tabular}{|c|c|c|c|c|}
\hline \multicolumn{2}{|l|}{ Variable } & Retail & \multicolumn{2}{|c|}{ Industrial } \\
\hline \multicolumn{2}{|l|}{ Panel C } & \multicolumn{3}{|c|}{ Mean Values for the main sectors } \\
\hline \multirow[t]{2}{*}{ Sale Price $(£)$} & SLBT & $9,147,172^{\star \star}$ & $48,816,547^{\star \star \star}$ & $11,245,124^{\star \star *}$ \\
\hline & NonSLBT & $3,779,232$ & $9,643,133$ & $4,341,708$ \\
\hline \multirow[t]{2}{*}{ Net Initial Yield (\%) } & SLBT & $6.81^{* \star \star}$ & $6.37^{\star \star \star}$ & $7.08^{* \star *}$ \\
\hline & NonSLBT & 8.31 & 8.79 & 8.76 \\
\hline \multirow[t]{2}{*}{ Price Per SF $(£)$} & SLBT & 316.31 & $383.76^{*}$ & $96.51^{* *}$ \\
\hline & NonSLBT & 324.03 & 296.02 & 74.60 \\
\hline \multirow[t]{2}{*}{ Annual NOI $(£)$} & SLBT & $549,604^{* *}$ & $2,529,141^{* * *}$ & $717,448^{* *}$ \\
\hline & NonSLBT & 241,341 & 536,405 & 371,695 \\
\hline \multirow[t]{2}{*}{ Rent per SF $(£)$} & SLBT & 19.51 & $21.08^{*}$ & 6.40 \\
\hline & NonSLBT & 20.96 & 18.10 & 5.84 \\
\hline \multirow[t]{2}{*}{ Size (SF) } & SLBT & $40,527^{*}$ & $99,955^{\star \star *}$ & $155,361^{\star \star *}$ \\
\hline & NonSLBT & 17,407 & 28,230 & 61,812 \\
\hline \multirow[t]{2}{*}{ Age (years) } & SLBT & 67.00 & $46.00^{\star *}$ & 26.12 \\
\hline & NonSLBT & 72.78 & 63.65 & 25.29 \\
\hline \multirow[t]{2}{*}{$\mathrm{N}$} & SLBT & 73 & 127 & 122 \\
\hline & NonSLBT & 696 & 303 & 242 \\
\hline
\end{tabular}


Table 3: Sale Price Models - Dependent Variable In (Sale Price) ${ }^{7}$

\begin{tabular}{|c|c|c|c|c|c|}
\hline Explanatory Variable & $\begin{array}{l}\text { Total Sample } \\
\text { (1) }\end{array}$ & $\begin{array}{l}\text { Full Sample } \\
\text { 2012-2017 } \\
\text { (2) }\end{array}$ & $\begin{array}{l}\text { Retail } \\
\text { sample (3) }\end{array}$ & $\begin{array}{l}\text { Office } \\
\text { sample (4) }\end{array}$ & $\begin{array}{l}\text { Industrial } \\
\text { sample (5) }\end{array}$ \\
\hline Intercept (Constant) & $6.104^{\star * *}$ & $6.043^{* * \star}$ & $6.500^{* * *}$ & $5.060^{\star \star \star}$ & $4.824^{\star * *}$ \\
\hline $\begin{array}{l}\text { Sale and Leaseback } \\
\text { deals (SLB) } \\
\text { (t-stat) }\end{array}$ & $\begin{array}{l}0.201^{* * *} \\
(2.944)\end{array}$ & $\begin{array}{l}0.219^{* \star *} \\
(3.169)\end{array}$ & $\begin{array}{l}0.134 \\
(0.836)\end{array}$ & $\begin{array}{l}0.280^{\star * *} \\
(2.560)\end{array}$ & $\begin{array}{l}0.101 \\
(0.920)\end{array}$ \\
\hline $\begin{array}{l}\text { Log of Building Size } \\
\text { (LNSIZESF) }\end{array}$ & $0.902^{* * *}$ & $0.907^{* * *}$ & $0.870^{\star \star \star}$ & $0.972^{\star \star \star}$ & $0.926^{\star * *}$ \\
\hline DV Retail & -0.148 & $-0.186^{\star \star}$ & & & \\
\hline DV Office & $-0.266^{\star \star \star}$ & $-0.326^{\star \star \star}$ & & & \\
\hline DV Industrial & $-1.036^{\star \star \star}$ & $-1.050^{\star \star \star}$ & & & \\
\hline DV London & $1.048^{\star \star \star}$ & $1.109^{* \star *}$ & $0.991^{\star \star \star}$ & $1.328^{\star \star \star}$ & $1.001^{* \star *}$ \\
\hline DV South_East & $0.218^{* * *}$ & $0.229^{* * *}$ & $0.289^{* * *}$ & $0.198^{*}$ & $0.192^{\star *}$ \\
\hline Building Age & $0.003^{\star * *}$ & $0.002^{* \star \star}$ & $0.002^{\star \star \star}$ & $0.003^{\star \star \star}$ & -0.001 \\
\hline DV 2-Star & 0.002 & 0.013 & 0.111 & -0.334 & 0.320 \\
\hline DV 3-Star & 0.262 & 0.238 & 0.334 & -0.312 & 0.420 \\
\hline DV 4-Star & $0.805^{\star * *}$ & $0.797^{\star \star *}$ & $1.005^{* *}$ & -0.056 & $0.648^{*}$ \\
\hline DV 5-Star & $1.126^{\star \star \star}$ & $1.992^{\star \star \star}$ & $3.223^{\star * \star}$ & 0.321 & \\
\hline DV 2006 & 0.123 & & & & \\
\hline DV 2007 & 0.262 & & & & \\
\hline DV 2008 & 0.106 & & & & \\
\hline DV 2009 & -0.201 & & & & \\
\hline DV 2010 & -0.124 & & & & \\
\hline DV 2011 & -0.048 & & & & \\
\hline DV 2012 & -0.134 & & & & \\
\hline DV 2013 & -0.062 & 0.092 & 0.080 & -0.051 & 0.196 \\
\hline DV 2014 & -0.034 & 0.118 & 0.033 & 0.122 & 0.193 \\
\hline DV 2015 & -0.059 & 0.096 & 0.026 & 0.126 & $0.256^{\star *}$ \\
\hline DV 2016 & -0.039 & $0.121^{*}$ & -0.053 & 0.223 & $0.421^{* * *}$ \\
\hline DV 2017 & -0.083 & 0.068 & -0.183 & 0.208 & $0.370^{\star \star}$ \\
\hline Adj R squared & 0.854 & 0.852 & 0.779 & 0.898 & 0.898 \\
\hline F- test & 373.55 & 452.24 & 163.92 & 199.80 & 187.14 \\
\hline Sig & 0.00 & 0.00 & 0.00 & 0.00 & 0.00 \\
\hline No of observations & 1623 & 1432 & 714 & 357 & 312 \\
\hline SLB Price Premium & $22.3 \%$ & $24.5 \%$ & $14.3 \%$ & $32.3 \%$ & $10.6 \%$ \\
\hline
\end{tabular}

\footnotetext{
${ }^{7}$ The significance levels $10 \%, 5 \%$ and $1 \%$ are denoted as ${ }^{*},{ }^{* *}$ and ${ }^{* * *}$, respectively. For clarity, t-stats are shown only for the SLB coefficient, but are available for all coefficients from the authors upon request.
} 
Table 4: Sale Price Models - Dependent Variable ln (PSF)

\begin{tabular}{|c|c|c|c|c|c|}
\hline $\begin{array}{l}\text { Explanatory } \\
\text { Variable }\end{array}$ & $\begin{array}{l}\text { Total Sample } \\
\text { (1) }\end{array}$ & $\begin{array}{l}\text { Full Sample } \\
\text { 2012-2017 (2) }\end{array}$ & $\begin{array}{l}\text { Retail } \\
\text { sample (3) }\end{array}$ & $\begin{array}{l}\text { Office } \\
\text { sample } \\
\text { (4) }\end{array}$ & $\begin{array}{l}\text { Industrial } \\
\text { sample (5) }\end{array}$ \\
\hline Intercept & $6.115^{\star \star \star}$ & $6.054^{* * *}$ & $6.500^{\star \star \star}$ & $5.060^{\star \star \star}$ & $4.824^{\star \star \star}$ \\
\hline DV SLB & $0.199^{* * *}$ & $0.217^{* \star *}$ & 0.134 & $0.280^{\star * *}$ & 0.101 \\
\hline (t-stat) & $(2.914)$ & $(3.136)$ & $(0.836)$ & $(2.560)$ & $(0.919)$ \\
\hline Ln (Size) & $-0.098^{\star * \star}$ & $-0.093^{\star \star *}$ & $-0.130^{\star \star \star}$ & -0.028 & -0.074 \\
\hline DV Retail & -0.160 & $-0.201^{*}$ & & & \\
\hline DV Office & $-0.278^{\star \star \star}$ & $-0.341^{\star \star \star}$ & & & \\
\hline DV Industrial & $-1.046^{* * *}$ & $-1.063^{* \star *}$ & & & \\
\hline DV London & $1.049^{\star \star *}$ & $1.110^{\star \star \star}$ & $0.991^{* * *}$ & $1.328^{\star \star \star}$ & $1.001^{* * *}$ \\
\hline DV South_East & $0.218^{\star \star \star}$ & $0.229^{\star \star \star}$ & $0.289^{\star \star \star}$ & $0.198^{*}$ & $0.192^{\star \star}$ \\
\hline Building Age & $0.003^{* * *}$ & $0.002^{* * *}$ & $0.002^{* *}$ & $0.003^{* * *}$ & -0.001 \\
\hline DV 2-Star & 0.003 & 0.013 & 0.110 & -0.339 & 0.320 \\
\hline DV 3-Star & 0.263 & 0.239 & 0.334 & -0.312 & 0.420 \\
\hline DV 4-Star & $0.807^{* * *}$ & $0.799^{* * *}$ & $1.005^{* *}$ & -0.056 & $0.648^{*}$ \\
\hline DV 5-Star & $1.801^{\star \star \star}$ & $2.104^{\star \star \star}$ & $3.223^{\star * \star}$ & 0.321 & \\
\hline DV 2006 & 0.121 & & & & \\
\hline DV 2007 & 0.260 & & & & \\
\hline DV 2008 & 0.106 & & & & \\
\hline DV 2009 & -0.203 & & & & \\
\hline DV 2010 & -0.125 & & & & \\
\hline DV 2011 & -0.053 & & & & \\
\hline DV 2012 & -0.135 & & & & \\
\hline DV 2013 & -0.062 & 0.094 & 0.080 & -0.051 & 0.196 \\
\hline DV 2014 & -0.034 & 0.121 & 0.033 & 0.122 & 0.193 \\
\hline DV 2015 & -0.058 & 0.100 & -0.026 & 0.126 & $0.256^{\star *}$ \\
\hline DV 2016 & -0.039 & $0.123^{*}$ & -0.053 & 0.223 & $0.421^{* * *}$ \\
\hline DV 2017 & -0.084 & 0.069 & -0.183 & 0.208 & $0.370^{\star *}$ \\
\hline Adj R squared & 0.480 & 0.490 & 0.307 & 0.514 & 0.263 \\
\hline F- test & 59.04 & 75.33 & 20.56 & 24.02 & 7.581 \\
\hline Sig & 0.00 & 0.00 & 0.00 & 0.00 & 0.00 \\
\hline $\begin{array}{l}\text { No of } \\
\text { observations }\end{array}$ & 1623 & 1432 & 714 & 357 & 312 \\
\hline Premium & $22.0 \%$ & $24.2 \%$ & $14.3 \%$ & $32.3 \%$ & $10.6 \%$ \\
\hline
\end{tabular}


Table 5: Initial Yield Models - Dependent Variable Net Initial Yield

\begin{tabular}{|c|c|c|c|c|c|}
\hline Explanatory Variable & $\begin{array}{l}\text { Total } \\
\text { Sample (1) }\end{array}$ & $\begin{array}{l}\text { Full Sample } \\
\text { 2012-2017 (2) }\end{array}$ & $\begin{array}{l}\text { Retail } \\
\text { sample (3) }\end{array}$ & $\begin{array}{l}\text { Office } \\
\text { sample (4) }\end{array}$ & $\begin{array}{l}\text { Industrial } \\
\text { sample (5) }\end{array}$ \\
\hline Intercept (Constant) & $9.234^{\star \star \star}$ & $9.997^{* * *}$ & $9.953^{* * *}$ & $11.888^{* * *}$ & $9.853^{\star \star \star}$ \\
\hline $\begin{array}{l}\text { SLB DV } \\
\text { (t-stat) }\end{array}$ & $\begin{array}{l}-1.693^{* * *} \\
(-6.617)\end{array}$ & $\begin{array}{l}-1.879^{* * *} \\
(-6.993)\end{array}$ & $\begin{array}{l}-2.215^{\star * *} \\
(-3.819)\end{array}$ & $\begin{array}{l}-1.656^{* * *} \\
(-3.343)\end{array}$ & $\begin{array}{l}-1.887^{* * *} \\
(-3.991)\end{array}$ \\
\hline $\begin{array}{l}\text { Log of Building Size } \\
\text { (LNSIZESF) }\end{array}$ & $-0.096^{* *}$ & $-0.059^{* *}$ & $-0.150^{* \star}$ & -0.102 & 0.058 \\
\hline DV Retail & 0.524 & $0.716^{*}$ & & & \\
\hline DV Office & $1.241^{\star \star \star}$ & $1.443^{\star \star \star}$ & & & \\
\hline DV Industrial & $0.849^{* *}$ & $0.949^{* *}$ & & & \\
\hline DV London & $-2.673^{\star \star \star}$ & $-2.940^{\star \star *}$ & $-3.036^{\star \star \star}$ & $-3.400^{\star \star \star}$ & $-2.629^{\star \star \star}$ \\
\hline DV South_East & $-0.968^{* * *}$ & $-1.115^{\star \star *}$ & $-1.297^{* * *}$ & -0.759 & $-1.005^{\star *}$ \\
\hline Building Age & $-0.004^{\star *}$ & $-0.004^{* *}$ & 0.002 & $-0.008^{\star \star \star}$ & 0.011 \\
\hline DV 2-Star & -0.096 & -0.175 & -0.506 & 1.261 & -0.240 \\
\hline DV 3-Star & -0.488 & -0.451 & -0.349 & 0.208 & -0.320 \\
\hline DV 4-Star & -1.219 & -1.223 & -1.769 & 0.119 & -1.339 \\
\hline DV 5-Star & -1.124 & -1.908 & -3.814 & -0.072 & \\
\hline DV 2006 & -0.959 & & & & \\
\hline DV 2007 & -0.341 & & & & \\
\hline DV 2008 & -0.392 & & & & \\
\hline DV 2009 & 0.931 & & & & \\
\hline DV 2010 & 0.643 & & & & \\
\hline DV 2011 & 0.114 & & & & \\
\hline DV 2012 & $1.623^{* *}$ & & & & \\
\hline DV 2013 & $1.326^{\star *}$ & -0.100 & 0.384 & -0.231 & -0.786 \\
\hline DV 2014 & 0.705 & $-0.713^{* *}$ & $-0.787^{*}$ & -0.817 & -0.557 \\
\hline DV 2015 & 0.752 & $-0.679^{* *}$ & -0.348 & $-1.110^{*}$ & $-0.955^{\star *}$ \\
\hline DV 2016 & 0.388 & $-1.055^{\star \star \star}$ & -0.465 & $-1.108^{* * *}$ & $-1.849^{* * \star}$ \\
\hline DV 2017 & 0.191 & $-1.201^{* \star \star}$ & -0.226 & $-1.848^{\star \star}$ & $-2.361^{\star * \star}$ \\
\hline Adj R squared & 0.219 & 0.224 & 0.184 & 0.320 & 0.220 \\
\hline F- test & 17.94 & 22.64 & 10.45 & 10.705 & 5.988 \\
\hline Sig & 0 & 0 & 0 & 0 & 0 \\
\hline No of observations & 1623 & 1432 & 714 & 357 & 312 \\
\hline $\begin{array}{l}\text { NIY discount for SLB } \\
\text { (percentage points) }\end{array}$ & $1.69 \%$ & $1.88 \%$ & $2.22 \%$ & $1.66 \%$ & $1.89 \%$ \\
\hline $\begin{array}{l}\text { NIY discount for SLB } \\
\text { (percent) }\end{array}$ & $18.3 \%$ & $18.8 \%$ & $22.3 \%$ & $13.9 \%$ & $19.2 \%$ \\
\hline
\end{tabular}


Table 6: Tenant Covenant Strength classification

\begin{tabular}{|l|l|l|l|l|l|l|l|}
\hline $\begin{array}{l}\text { Risk } \\
\text { Category }\end{array}$ & $\begin{array}{l}\text { D\&B Risk } \\
\text { Rating }\end{array}$ & $\begin{array}{l}\text { D\&B } \\
\text { Score }\end{array}$ & S\&P & ICC & CreditSafe & Qui & Experian \\
\hline Very Low & 1 & $72-100$ & $\begin{array}{l}\text { AA to } \\
\text { AAA }\end{array}$ & $72-100$ & $80-100$ & $80-100$ & Very Low \\
\hline Low & 2 & $54-71$ & A & $54-71$ & $60-80$ & $60-80$ & Low \\
\hline Medium & 3 & $41-53$ & BBB & $41-53$ & $40-60$ & $40-60$ & Marked \\
\hline High & 4 & $30-40$ & BB or B & $30-40$ & $20-40$ & $20-40$ & High \\
\hline Very High & 5 & $1-29$ & C to D & $1-29$ & $0-20$ & $0-20$ & Very High \\
\hline
\end{tabular}


Table 7: Sale Price and NIY Models including lease length and covenant strength

\begin{tabular}{|c|c|c|c|}
\hline Explanatory Variable & Ln (Price) & Ln PSF & NIY \\
\hline Intercept (Constant) & $5.999 * * *$ & $6.016^{\star * *}$ & $9.379^{* * *}$ \\
\hline $\begin{array}{l}\text { Sale and Leaseback deals } \\
\text { (SLB) } \\
\text { (t-stat) }\end{array}$ & $\begin{array}{l}0.042 \\
(0.509)\end{array}$ & $\begin{array}{l}0.040 \\
(0.476)\end{array}$ & $\begin{array}{l}-1.020^{\star * *} \\
(-3.217)\end{array}$ \\
\hline $\begin{array}{l}\text { Log of Building Size } \\
\text { (LNSIZESF) }\end{array}$ & $0.879^{\star \star \star}$ & $-0.121^{\star \star *}$ & $-0.178^{\star \star *}$ \\
\hline DV Retail & -0.056 & $-0.083^{\star * \star}$ & 0.682 \\
\hline DV Office & -0.121 & -0.148 & $1.168^{*}$ \\
\hline DV Industrial & $-0.892^{* \star *}$ & $-0.917^{\star * \star}$ & 1.044 \\
\hline DV London & $1.004^{\star \star *}$ & $1.005^{\star \star *}$ & $-2.672^{\star \star *}$ \\
\hline DV South_East & $0.241^{\star * *}$ & $0.242^{\star \star \star}$ & $-1.044^{\star \star *}$ \\
\hline Building Age (AGE) $(\mathrm{N}=901)$ & $0.003^{\star * *}$ & $0.003^{\star * *}$ & $-0.003^{*}$ \\
\hline DV 2-Star $(\mathrm{N}=403)$ & -0.175 & -0.175 & 0.044 \\
\hline DV 3-Star ( $N=848)$ & 0.089 & 0.089 & -0.348 \\
\hline DV 4-Star $(\mathrm{N}=142)$ & $0.619^{*}$ & $0.621^{*}$ & $-1.094^{*}$ \\
\hline DV 5-Star (N=13) & $1.551^{\star * *}$ & $1.612^{\star \star \star}$ & -1.128 \\
\hline DV Medium $(\mathrm{N}=128)$ & $0.169^{\star}$ & $0.168^{\star \star}$ & -0.150 \\
\hline DV Long $(\mathrm{N}=92)$ & $0.178^{*}$ & $0.176^{*}$ & 0.047 \\
\hline DV Very Long $(\mathrm{N}=103)$ & $0.370^{\star *}$ & $0.364^{\star *}$ & $-0.876^{\star \star}$ \\
\hline DV Very Low Risk $(\mathrm{N}=119)$ & $0.144^{*}$ & $0.144^{*}$ & -0.323 \\
\hline DV Low Risk $(\mathrm{N}=16)$ & 0.009 & 0.008 & -0.101 \\
\hline DV Medium Risk $(\mathrm{N}=34)$ & -0.014 & -0.016 & 0.286 \\
\hline DV High Risk $(\mathrm{N}=4)$ & -0.403 & -0.409 & $0.688^{\star *}$ \\
\hline DV 2012 & -0.123 & -0.118 & $1.295^{\star * *}$ \\
\hline DV 2013 & -0.062 & -0.057 & $1.035^{\star \star}$ \\
\hline DV 2014 & -0.062 & -0.057 & $0.667^{\star *}$ \\
\hline DV 2015 & -0.157 & -0.149 & $0.749^{* *}$ \\
\hline DV 2016 & -0.054 & -0.048 & 0.268 \\
\hline DV 2017 & -0.043 & -0.037 & 0.057 \\
\hline R squared & 0.865 & 0.532 & 0.253 \\
\hline F- test & 225 & 40 & 12 \\
\hline Sig & 0 & 0 & 0 \\
\hline No of observations & 901 & 901 & 901 \\
\hline $\begin{array}{l}\text { SLB Price Premium / NIY } \\
\text { Discount }\end{array}$ & $4.29 \%$ & $4.08 \%$ & $1.02 \%$ \\
\hline
\end{tabular}


Figure 1: Yield Comparisons with risk-free rate

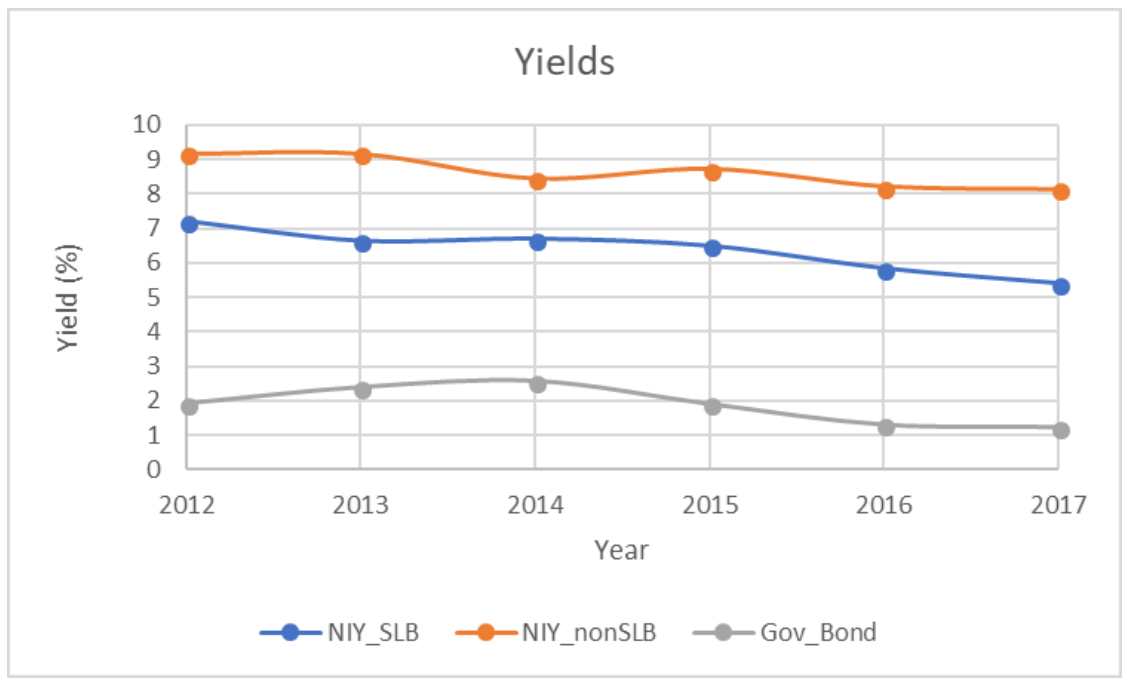




\section{Figure 2: Net Initial Yields by Sector}

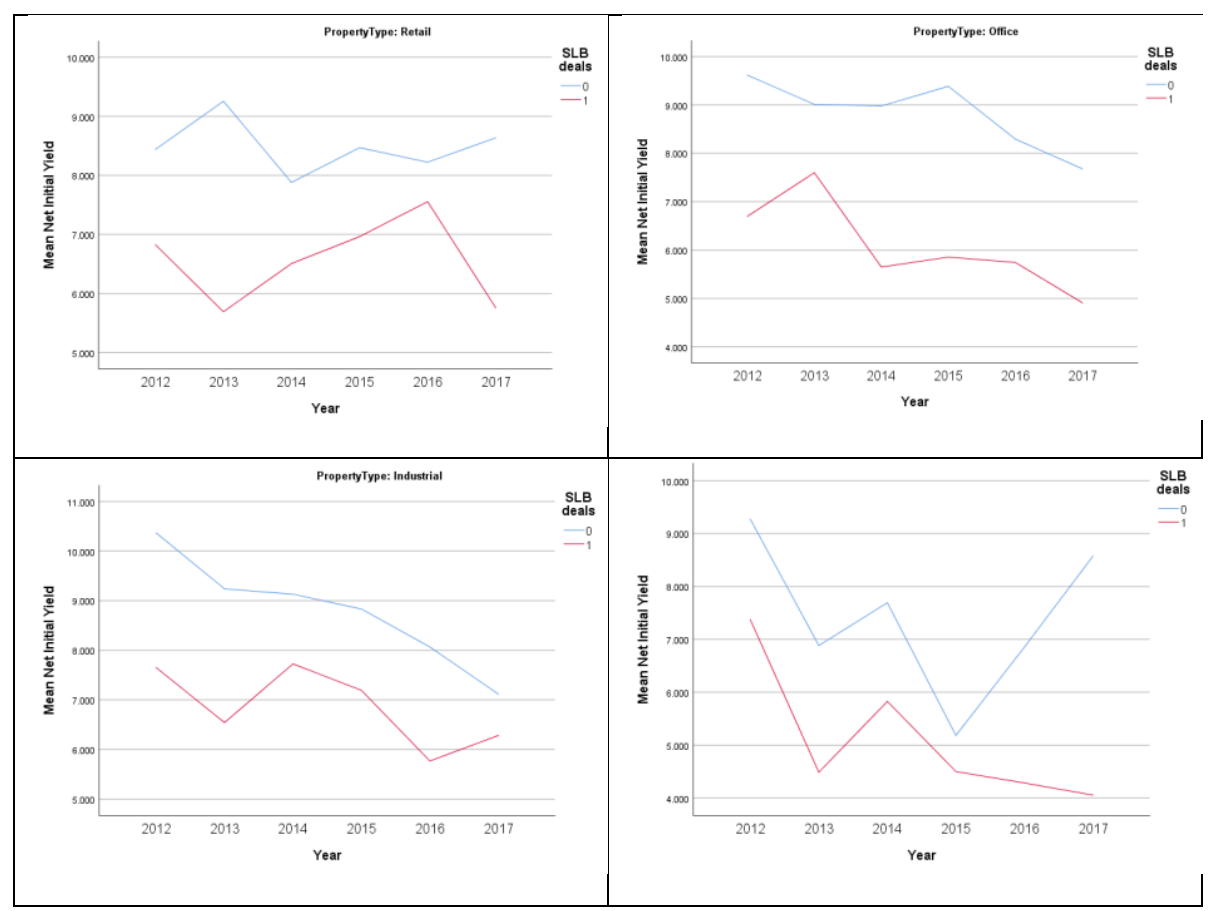

Key: $0=$ non-SLB

$1=$ SLB 
Figure 3: Comparison of Mean Sale Price of SLB sample with non-SLB transactions of various lease lengths and tenant covenant strengths

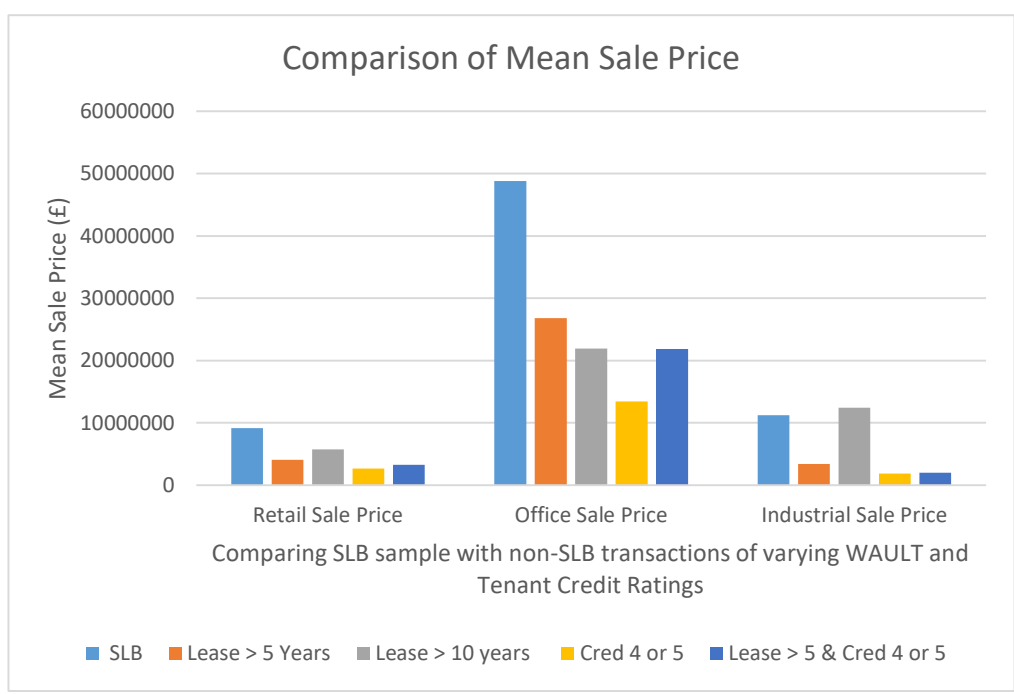

Figure 4: Comparison of NIY of SLB sample with non-SLB transactions of various lease lengths and tenant covenant strengths

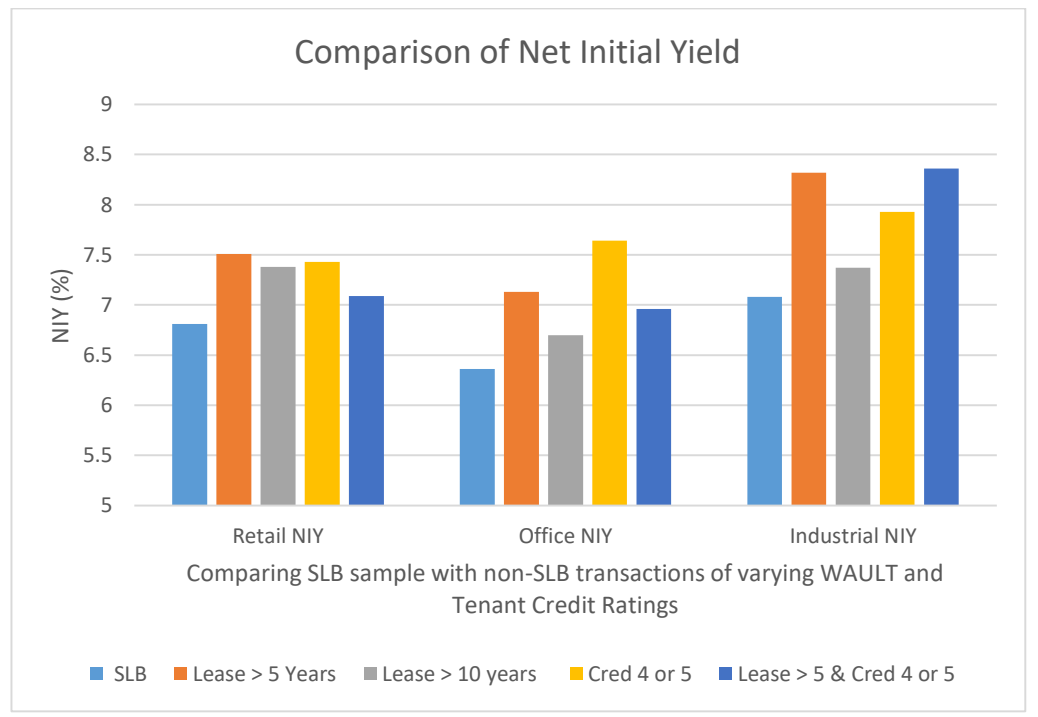

